\title{
The Estimation of Economic Appearance and Profitability Function of Drip Irrigation in Tidal Lands (a Case of Chili Farming)
}

\author{
Dessy Adriani ${ }^{1}$, Maryanah Hamzah ${ }^{1}$, and Muammar Adi Prasetya ${ }^{2}$ \\ ${ }^{I}$ Researcher of Agribusiness Study Program, Faculty of Agriculture, Universitas Sriwijaya \\ ${ }^{2}$ Research Assistant of Agribusiness Study Program, Faculty of Agriculture, Universitas Sriwijaya \\ *Corresponding Author: dessyadriani@fp.unsri.ac.id
}

\begin{tabular}{llll} 
Article history & & \\
\hline Received & Received in revised form & Accepted & Available online \\
07 Oct 2019 & 28 December 2019 & 28 December 2019 & 30 December 2019 \\
\hline
\end{tabular}

\begin{abstract}
The purpose of this research are (1) to determine economic appearance and (2) to estimate the profit function of the application of drip irrigation technology for chili farming in tidal lands. This research used survey method at Budi Mulya Village Air Kumbang Sub-district Banyuasin Regency. Collecting data was held on March and April of 2018. Sampling method was proportionate stratified random. Watering and fertilization of chili farming with utilizing drip irrigation technology was done by using water pump machine. Drip irrigation affected positive impact for increasing of chili farming profit. Drip irrigation technology in chili farming is more efficient than chili farming without drip irrigation technology. Economic of scales of drip irrigation technology in chili farming is 2.547 , that means in increasing returns to scale condition. Farmers need government policy in applying this technology like a subsidy or loan from government.
\end{abstract}

Keywords: dry, season, innovation, lowlands, profit

\section{Introduction}

To increase the productivity of paddy farming in tidal lands, various technology components can be developed [5] [6] [7] [11] [12] [16]. The components of agricultural machine tool technology and superior varieties accompanied with balanced fertilization can be an alternative improvement to the existing farming system. In some cases, increased productivity has been carried out through the implementation of rice-livestock integration systems, especially cattle, chickens, and ducks, or combined with fish [3], as well as the development of local resources (local wisdom), horticulture and other agribusinesses [8] [9] [13] [17].

Of course, there is great optimism regarding the success of tidal lands for food crop. Optimization of tidal lands to support the increasing of national food production program can be carried out because various technological innovations are available such as: (1) water and soil management technologies, including microwater management, lands management, amelioration and fertilization; (2) new superior varieties that are more adaptive and productive; and (3) agricultural tools and machinery suitable for the tidal lands. However, the development and optimization of tidal lands also faces non- technical barriers, including capital, labor availability, and technology mastery by farmers [10] [22]. [1] and [2] detailly stated that the use of technology has negative impact on an increasing unemployment by $3.87 \%$, and a decrease in work time allocation by $10.91 \%$, and positive impact on increasing profit and household productivity - respectively $362 \%$ and $388 \%$.

As stated earlier that the limitations of tidal lands in developing agricultural need to be supported by technology applications. The situation can be changed by technological innovations, such as drip irrigation. Drip irrigation is a system that uses plastic pipelines and drippers to deliver water at low pressure directly to the roots of plants. This technology is considered able to overcome the problem of water availability in the dry season on tidal lands. The drip irrigation system prevents most of the water loss through evaporation, run off, and soil erosion and weather changes [23].

One of the potential commodities developed in tidal lands, besides rice, is a horticultural crop. Horticultural plants that have potentially to be planted are chili. Red chili is a horticultural commodity that has a high selling and is usually cultivated in rural areas. The price is a driving factor for farmers to plant it. In 
general, red chili farmers concentrate their business in wet season, while in dry season there are not many farmers who cultivate it. So that the supply to the market will be limited and prices will rise on dry season. The dynamics of unpredictable weather and price changes make red chili farming also have a high risk.

Thus, weather and price conditions impact on the economic behavior of farmers mainly related to the risks faced. Farmers, who are commercial, usually have to calculate the costs and revenue. Costs have an important role to compare with the revenue. This means that the measurement of economic efficiency is very important to analysis to which each rupiah invested by farmers can provide profit. A good farm is always said to be a productive and efficient farm. Rupiah will turn into economic efficiency, in other words economic efficiency depends on the price of production factors and physical efficiency calculation. Based on this theory, the efficiency in this case is a balance between the total values of production with production costs [4] [15] [18].

During times, the use of the profit function in measuring efficiency has not been widely applied to horticultural crops on tidal lands. The profit function used in this study is the profit function derived from the Cobb-Douglas function, which is a function that involves the cost of production, factors in the form of natural logarithm [21]. This function is used to measure the effect of various changes in input and output. This technique is based on the assumption that the goal of farmers in production is to maximize profits.

Banyuasin Regency has an area of 11.875 $\mathrm{km}^{2}$, which has topography of 80 percent of wetlands in the form of tidal and swampy lands, while 20 percent is in dry lands. In this area, almost all farmers cultivated paddy farming, corn farming, oil palm plantation, and rubber plantation. In the late of 2015, some farmers group tried to cultivate chili in dry season. Solving the lack of water, they used drip irrigation. Chili farmers in the Air Kumbang District Banyuasin Regency have used drip irrigation technology to water and fertilize chili plants. Drip irrigation technology has begun with an expectation to plant chili farming in the dry season. Based on the description above, this study aims to determine economic appearance and estimate the profit function of the application of drip irrigation technology for chili farming in tidal lands.

\section{Material and Methods}

This research was conducted in Budi Mulya Village, Air Kumbang District, Banyuasin Regency. The location was selected purposively with the consideration that the farmers in the location were planted on chili by using drip irrigation technology in dry season. The research method is a survey method. There were two farmer groups in chili farming, namely with and without using drip irrigation. The numbers of farmers who use drip irrigation technology were 27 people with 19 samples and farmers who do not use drip irrigation were 10 people with 7 people. The sampling method was the stratified random sampling. Sources of data were primary and secondary. Data collected was analyzed quantitatively to assess the profit, the economic efficiency, and the economics scale of business by using profit function model.

The reason for using the profit function model according to [20], [24] related to several advantages, including:

1. The output supply function and the input demand function can be predicted together without having to make an explicit production function.

2. The profit function can be used to examine technical, price, and economic efficiency.

3 . In the profit function model, the observed variables are the cost and revenue variables.

The type of profit function that is widely used is the Cobb-Douglas profit function and the translog function. In Indonesia, the CobbDouglas profit function has been widely used for research on various types of businesses, as seen on [15] and [18]. The chili farming with the drip irrigation system also has a profit function that can generally be described through a process of mathematical decline based on [24] as follows. Suppose that the production function is: 


$$
\begin{aligned}
& Y=f\left(X_{1}, X_{2}, \ldots \ldots, X_{m} ; Z_{1}, Z_{2}, \ldots \ldots, Z\right) \ldots \ldots \ldots \ldots \ldots \ldots . . . \\
& \pi=p \cdot f\left(X_{1}, X_{2}, \ldots \ldots, X_{m} ; Z_{1}, Z_{2}, \ldots \ldots Z_{n}\right)-\Sigma W_{i} . X_{I} .
\end{aligned}
$$

Whereas:

$\pi$ : Short term profit

$\mathrm{p}$ : Output price per unit

$\mathrm{X}_{\mathrm{i}}$ : Variable input for $\mathrm{i}(\mathrm{i}=1,2, \ldots, \mathrm{m})$

$Z_{j}$ : Fixed input for-j $(j=1,2, \ldots, n)$

$\mathrm{W}_{\mathrm{i}}$ : Input price

According to [18], the specification of the profit function used in this study is the CobbDouglas profit function derived from the CobbDouglas production function. Through the process of deriving from equations (1) to (2) above, the Cobb Douglas profit function is obtained as follows:

$$
\ln \pi^{*}=\ln A^{*}+\alpha_{i}^{*} \cdot \ln W_{l}^{*}+b_{j}^{*} \cdot \ln W_{2}^{*}
$$

Whereas:
A : Intercept
$\pi * \quad$ : Profit (IDR / planting season)
$\mathrm{W}_{1} *$ : Labor Costs (IDR/ planting season)
$\mathrm{W}_{2} *$ : Capital Costs (IDR / planting season).
$\alpha_{\imath} *$ : Labor input coefficient.
$\beta_{\varphi} *$ : Capital input coefficient.

Proof whether the drip irrigation chili farming has Increasing Return to Scale (IRS), Constant Return to Scale (CRS), or Decreasing Return to Scale (DRS) conditions can be tested using the fixed input coefficient of the Cobb Douglas profit function [15], [19] using the following calculation:

If $\Sigma \beta \mathrm{i}=1$, the chili farming in drip irrigation system has a CRS condition

If $\Sigma \beta \mathrm{i}>1$, the chili farming business in drip irrigation system has an IRS condition
If $\Sigma \beta \mathrm{i}<1$, the chili cultivation business in drip irrigation system has DRS condition

\section{Results and Discussion}

3.1. Economic Performance of Drip Irrigation System Application for Chili Farming in Tidal Lands

\subsubsection{Costs, Revenue and Profit}

In this case the production costs include fixed costs and variable costs. The total production costs of farmers with and without using drip irrigation technology in the Tidal Lands can be seen in Table 1.

\begin{tabular}{|c|c|c|c|c|c|c|c|}
\hline \multirow{3}{*}{ No } & \multirow{3}{*}{ Cost } & \multicolumn{4}{|c|}{ Drip Irrigation Technology } & \multirow{3}{*}{ Differences } & \multirow{3}{*}{$(\%)$} \\
\hline & & \multicolumn{2}{|l|}{ Without } & \multicolumn{2}{|c|}{ With (IDR/ha/ planting season) } & & \\
\hline & & $\begin{array}{l}\text { (IDR/ha/planting } \\
\text { season) }\end{array}$ & $(\%)$ & $\begin{array}{l}\text { (IDR/ha/planting } \\
\text { season) }\end{array}$ & $(\%)$ & & \\
\hline 1 & Fixed Cost & $512,000.00$ & 1.81 & $3,590,925$ & 8.74 & $3,078,925.06$ & 601.35 \\
\hline 2 & $\begin{array}{l}\text { Variable } \\
\text { Cost }\end{array}$ & $27,732,000.00$ & 98.19 & $37,496,487$ & 91.26 & $9,764,487.12$ & 35.21 \\
\hline 3 & Total Cost & $28,244,000.00$ & 100.00 & $41,087,412.18$ & 100.00 & $12,843,412.18$ & 45.47 \\
\hline
\end{tabular}

Table 1. Production Costs of Chili Farming with and without Using Drip Irrigation Technology on Tidal Lands 
Based on Table 1, it can be seen that the total production costs in chili farming incurred by farmers using drip irrigation technology is greater than that for example farmers without using drip irrigation technology with a difference in the average total production cost of $12,863,412.00$ IDR/hectare/planting season. It means that there is an impact of the use of drip irrigation technology on the production costs of chili farming. This is caused by the farmers who use drip irrigation technology required pumping machines, drip hoses, and other agricultural equipment, so that there are an increasing in production costs.

The following Table 2 is showing the revenue comparison of chili farming between using and not using drip irrigation technology.

Table 2. Revenue of Chili Farms With and Without Using Drip Irrigation Technology on Tidal Lands.

\begin{tabular}{|c|c|c|c|c|c|}
\hline \multirow[b]{2}{*}{ No } & \multirow[b]{2}{*}{ Component } & \multicolumn{2}{|c|}{ Drip Irrigation Technology } & \multirow[b]{2}{*}{ Differences } & \multirow[b]{2}{*}{$(\%)$} \\
\hline & & Without & With & & \\
\hline 1 & $\begin{array}{l}\text { Production } \\
(\mathrm{Kg} / \mathrm{Ha})\end{array}$ & $1,560.00$ & $3,152.00$ & $1,592.00$ & 102.05 \\
\hline 2 & Price (IDR/kg) & $29,200.00$ & $26,000.00$ & $(3,200.00)$ & -10.96 \\
\hline 3 & $\begin{array}{l}\text { Revenue } \\
\text { (IDR/kg/planting } \\
\text { season) }\end{array}$ & $45,552,000.00$ & $81,952,000.00$ & $36,400,000.00$ & 79.91 \\
\hline
\end{tabular}

Based on Table 2, it can be seen that the revenue in chili farming received by farmers using drip irrigation technology is greater than that for farmers without using drip irrigation technology with a difference of revenue of 36,400,000.00 IDR/hectare/planting season. The difference in revenue is due to the production produced by farmers using drip irrigation technology is higher than farmers without using drip irrigation technology, the average production difference of 1,592 $\mathrm{kg} / \mathrm{hectare} /$ planting season, which means the impact of the application of drip irrigation technology on the revenue of chili farming.

After analyzing the amount of revenue from chili farming, then we can calculated the amount of profit that will be received by the farmers can be seen in Table 3 .

Table 3. Profit of Chili Farms With and Without Using Drip Irrigation Technology on Tidal Lands

\begin{tabular}{llrrrr}
\hline & & \multicolumn{2}{c}{ Drip Irrigation Technology } & \\
\cline { 3 - 5 } No & Component & $\begin{array}{c}\text { Without (IDR/ha/ } \\
\text { planting season) }\end{array}$ & $\begin{array}{c}\text { With } \\
(\text { IDR/ha/ planting season) }\end{array}$ & Differences \\
& Revenue & $45,552,000.00$ & $81,952,000.00$ & $36,400,000.00$ & 79.91 \\
1 & Total Cost & $28,244,000.00$ & $41,087,412.18$ & $12,843,412.18$ & 45.47 \\
3 & Profit & $17,308,000.00$ & $40,864,587.82$ & $23,592,878.82$ & 136.10 \\
\hline
\end{tabular}

Based on Table 3, it can be seen that the chili farming farm profit without using drip irrigation technology is $17,308,000.00$ IDR/hectare/planting seasons, while the profit of farmers using drip irrigation technology was 40,900,878.00 IDR/hectare/planting season. The profit of chili farming from farmers using drip irrigation technology is greater than farmers without using drip irrigation technology with an profit difference of 23,592,878.82 IDR/hectare/planting season. It means there is a positive impact of application of drip irrigation technology on the profit of chili farming.
Comparison of profit is done between chili farming profit using drip irrigation technology and chili farming profit without using drip irrigation technology. The difference in profit received by farmers with and without using of drip irrigation technology can be determined by using parametric statistical analysis, namely the t-test. But before calculating the comparison using the t-test values, it is necessary to know first whether the data distribution is normally distributed (Table 4). 
Table 4. Kolmogorov-Smirnov Normality Test Results

\begin{tabular}{|c|c|c|}
\hline No & Variable & Probability \\
\hline 1 & Using Drip Irrigation Technology & 0,20 \\
\hline 2 & $\begin{array}{l}\text { Without Using Drip Irrigation } \\
\text { Technology }\end{array}$ & 0,06 \\
\hline \multicolumn{2}{|r|}{ Result } & Normal \\
\hline
\end{tabular}

The results of the normality test with a significance value for farmers using drip irrigation technology is 0.06 greater than $\alpha$ at 0.05 and for farmers without using drip irrigation technology is 0.20 greater than $\alpha$ at 0.05 . So, it means they are normally distributed.

Furthermore, the comparison of farmers' chili profit with and without using drip irrigation technology can be seen in Table 5 .

Table 5. Results of t-Test Analysis of Profit of Chili Farmers With and Without Using Drip Irrigation Technology in Tidal Lands

\begin{tabular}{clc}
\hline No & Component & Result \\
\hline 1 & t-value & 2.558 \\
2 & t-table $(0.05 ; 19)$ & 2.110 \\
3 & Sign. $(2$-tailed) & 0.05 \\
\hline \multicolumn{2}{c}{ Result } & Ho Rejected
\end{tabular}

Based on Table 5 can be seen that the tvalue of 2.558 obtained from data processing using SPSS and the significance level of $\alpha=0.05$ was chosen in the t-table of 2.110. It can be seen that the t-value is greater than the t-table, so the decision is rejected of $\mathrm{Ho}$ at 95 percent of confidence level. The chili farmers' profit with and without using drip irrigation is different significantly. This t-test proves that the use of drip irrigation technology has an impact on increasing chili-farming profit.

\subsubsection{Efficiency of Chili Farm in Tidal Lands}

Table 6 presents the $\mathrm{R} / \mathrm{C}$ and $\mathrm{B} / \mathrm{C}$ value of chili farming with and without using drip irrigation technology. $\mathrm{B} / \mathrm{C}$ value is used also as efficiency criteria in this research, although in many cases, $\mathrm{B} / \mathrm{C}$ is recently used for long term and large-scale business analysis. Chili farming with and without using drip irrigation technology is equally feasible or efficient. R/C value of chili farming without drip irrigation technology is 1.61 while those using drip irrigation are 2.00. Furthermore, chili farming without using drip irrigation technology has a $\mathrm{B} / \mathrm{C}$ value of 0.61 meaning greater than zero and similar to chili farming using drip irrigation can be said to be efficient with a B/C value of one. Difference in profit from chili farming with and without using drip irrigation technology, amounting to IDR $23,592,878.82$ while the value of the difference in the production cost of chili farming profit with and without using drip irrigation technology is IDR $10,314,956.00$ so we get an Incremental Ratio value of 2.29 . It means that each additional 1 unit of cost will add 2.29 unit of profit.

If we compare between Chili Farming Without and Using Drip Irrigation Technology on Tidal Lands, it shows Chili Farming with using Drip Irrigation Technology is more efficient that without using it.

Table 6. R/C and B/C of Chili Farms Without and With Using Drip Irrigation Technology on Tidal Lands

\begin{tabular}{clcccc}
\hline No & Drip Irrigation Technology & $\mathrm{R} / \mathrm{C}$ & $\mathrm{B} / \mathrm{C}$ & $\begin{array}{c}\text { Incremental } \\
\text { Ratio }\end{array}$ & Result \\
\hline 1 & Without & 1.61 & 0.61 & 2.29 & Efficient \\
2 & With & 2.00 & 1.00 & & Efficient \\
\hline
\end{tabular}

3.2. Estimation of the Profit Function of Drip Irrigation System Application in Tidal Lands in Chili Farming
Based on the estimation results using the OLS (Ordinary Least Square) method the results can be seen as listed in Table 7 as follows: 
Table 7. Results of estimating parameters Function of Advantages of Chili Farming Using Drip Irrigation Technology on Tidal Lands

\begin{tabular}{lccc}
\hline \multicolumn{1}{c}{ Variable } & Coefficient & t-value & $p$-Value \\
\hline Constanta & -0.913 & -0.792 & 0.445 \\
Labor & 2.827 & 2.736 & $0.019^{*}$ \\
Capital & -0.280 & -0.305 & 0.766 \\
\hline $\mathrm{R}^{2}=0.416$ & F-value 3.386 & Sig-F 0.052 & \\
\hline
\end{tabular}

Note: * Significantly influential at the level of 0.05

The estimation results of the model by the Ordinary Least Square (OLS) method show that the model is representative enough to estimate the profit function of chili farming by using Drip Irrigation Technology. The coefficient of determination $\left(\mathrm{R}^{2}\right)$ in the equation is quite high $0.416\left(\mathrm{R}^{2}=41.6 \%\right)$. This shows that all explanatory variables in the model can explain the behavior of the model well. The explanatory variables in each equation together quite clearly explain the diversity of dependent variables as shown by the statistical value of $F$ value of 3.386 which significant at the 0.05 levels.
There is no violation of classic assumption. Multicollinearity test resulted with a VIF value of 1.111. Based on t-test, the most important things and the main orientation of this research is all allegations of parameters in the model in line with expectations based on both theory and economic logic, linier with [14] finding research result. The results of the t-test showed that partially profit was significantly affected by the labor as explanatory variables of at the level of $\alpha$ 0.05 .

The form of the Profit Function is as follows:

$$
\begin{aligned}
& \text { Ln. } \pi^{*}=-8.184+2.827 \cdot \operatorname{Ln} \cdot W_{1}^{*}-0,280 \cdot \operatorname{Ln} W_{2}{ }^{*} \\
& \text { Ln. } \pi^{*}=0.1913 \text { Ln. } W_{1}{ }^{2.827^{*}} \text { Ln. } W_{2}{ }^{0.280^{*}}
\end{aligned}
$$

The explanatory variable of labor has a positive effect on the profitability of chili farming with a drip irrigation system on tidal lands. The regression coefficient is 2.827 . This value means that if labor use increases by 1 percent, profits increase by 2.827 percent. In economic perspective, it also means the chancing of labor is very elastic to the chancing of chili farmers' profit. The chili farming needs more labor in applying drip irrigation. The independent variable of capital has no significant effect on the profitability of chili farming with drip irrigation in tidal lands.

The economic condition of the business scale is increasing returns to scale where this reality is supported by the value of $\Sigma \beta$ i greater than one, which is 2.547 (Table 7). This means that any increase in input in the long run is always followed by an increase in output with increasing results.

As explain di the beginning of this paper, farmers use drip irrigation on dry season solving the lack of water. This research proves farmers is not only can solve the lack of water, but also can reach the greater profit by using the drip irrigation farmers. But, most of farmers face the lack of capital cost in Appling this technology. So, farmers need government policy in applying this technology like a subsidy or loan from government.

\section{Conclusion}

Watering and fertilization of chili farming with utilizing drip irrigation technology was done by using water pump machine. The use of drip irrigation technology has a significant impact on increasing chili-farming profit. Chili Farming with using drip irrigation technology is more efficient that without using it. Economic conditions on a business scale are increasing returns to scale where this reality is supported by a value of $\Sigma \beta_{\mathrm{j}}$ greater than one, which are 2.547. This means that any increase in input in the long run is always followed by an increase in output with increasing results. This research proves farmers is not only can solve the lack of water, but also can reach the greater profit by using the 
drip irrigation farmers. But, most of farmers face the lack of capital cost in applying this technology. So, farmers need government policy in applying this technology like a subsidy or loan from government.

\section{References}

[1] Adriani, Dessy. Wildayana, E., Yulius., Alamsyah I., and M.M.Hakim, 2017. Technological Innovation And Business Diversification: Sustainability Livelihoods Improvement Scenario Of Rice Farmer Household In Sub-Optimal Lands. RJOAS, 9(69): 77-88.

[2] Adriani, Dessy. and E. Wildayana. 2019. Finding Policies of Disguised Unemployment Arrangement: Through Various Technological Innovations of Agriculture and Profit Diversification for Tidal Rice Farmer. Sriwijaya Journal of Environment Vol. 3 No. 3, 113-122.

[3] Diwyanto, K., D.M. Arsyad, D.K. Sadra, A. Mulyani, D.S. Effendi, I. Las, Endrizal, and B. B. Saidi. 2012. Laporan Kunjungan Kerja Tematik dan Penyusunan Model Percepatan Pembangunan Pertanian Berbasis Inovasi di Lahan Suboptimal Rawa Pasang Surut Kabupaten Tanjung Jabung Timur Provinsi Jambi. Center for Research and Development of Agricultural Land Resources. Bogor.

[4] Hadiana, M. H. 1990. Pendugaan Skala Usaha, Respon Suplai, dan Efisiensi Ekonomi Relatif Peternakan Sapi Perah. Thesis. Postgraduate Faculty. Bogor Agricultural Institute. Bogor.

[5] Hartatik, W. and D.A. Suriadikarta. 2006. Teknologi pengelolaan hara lahan gambut. hlm. 151-180. In D.A. Suriadikarta, U. Kurnia, Mamat H.S., W. Hartatik, dan D. Setyorini (Ed.). Karakteristik dan Pengelolaan Lahan Rawa. Pengembangan Inovasi Pertanian Vol. 7 No. 4: 169-176.

[6] Haryono, M. Noor, M. Sarwani, and H. Syahbuddin. 2012. Lahan Rawa: Penelitian dan Pengembangan. IAARD Press Jakarta. $102 \mathrm{hlm}$.
[7] Haryono. 2013. Lahan Rawa: Lumbung Pangan Masa Depan Indonesia. IAARD Press. Jakarta. $141 \mathrm{hlm}$.

[8] Jumberi, A. and T. Alihamsyah. 2006. Usaha agribisnis di lahan rawa pasang surut. Pp. 275-297. In D.A. Suriadikarta, U. Kurnia, Mamat H.S., W. Hartatik, dan D. Setyorini (Ed.). Karakteristik dan Pengelolaan Lahan Rawa. Center for Research and Development of Agricultural Land Resources. Bogor.

[9] Khairullah, I. and M. Saleh. 2014. Sumberdaya lokal tanaman pangan lahan rawa. hlm. 21-37. In Mukhlis, M. Noor, M. Alwi, M. Thamrin, D. Nursyamsi dan Haryono (Ed.). Biodiversiti Rawa: Eksplorasi, Penelitian dan Pelestariannya. IAARD Press, Jakarta.

[10] Lakitan, Benyamin. 2013. Connecting all the dots: Identifying the "actor level" challenges in establishing effective innovation system in Indonesia. Technology in Society. Volume 35 (1) : 41-54.

[11] Noor, M., M. Alwi, and K. Anwar. 2007. Kearifan lokal dalam perspektif kesuburan tanah dan konservasi air di lahan gambut. hlm. 87-93. Dalam Mukhlis, I. Noor, M. Noor, dan R.S. Simatupang (Ed.). Kearifan Lokal Pertanian di Lahan Rawa. Swamp Farm Research Institute. Banjarbaru.

[12] Noor, M., A. Hairani, and S. Nurzakiah. 2011. Perbaikan sifat kimia, status hara, dan hasil padi pada lahan gambut pasang surut Kalimantan Tengah. hlm. 131-144. Dalam B. Kartiwa, E. Runtunuwu, Subowo, M. Anda, A. Dariah, Mukhlis, A. Nugraha, dan P. Setyanto (Ed.). Proceeding of the National Seminar on Agricultural Land Resources. 3rd Book. Center for Research and Development of Agricultural Land Resources. Bogor

[13] Noorginayuwati and A. Rafieq. 2007. Kearifan lokal dalam pemanfaatan lahan lebak untuk pertanian di Kalimantan Selatan. In Mukhlis, I. Noor, M. Noor, dan R.S. Simatupang (Ed.). Kearifan Lokal 
Pertanian di Lahan Rawa. Swamp Farm Research Institute. Banjarbaru.

[14] Nurung, Muhammad. Estimasi Fungsi Keuntungan dan Efisiensi Alokatif Usahatani Padi Sawah Pada Petani Pemilik Lahan dan Penyakap di Desa Kemumu Kec. Agramakmur Kab. Bengkulu Utara". Jurnal Penelitian Unib, Vol. VIII (No.1): 19-23.

[15] Mandaka and Parulian. 2005. Analisis Fungsi Keuntungan, Efisiensi Ekonomi Dan Kemungkinan Skema Kredit Bagi Pengembangan Skala Usaha Peternakan Sapi Perah Rakyat Di Kelurahan Kebon Pedes, Kota Bogor. . Jurnal Agro Ekonomi, Volume 23 (No.2): 191-208

[16] Mukhlis, Y. Rina, and R.S. Simatupang. 2011. Pemanfaatan mulsa pada sistem surjan untuk meningkatkan produktivitas tanaman di lahan rawa lebak tengahan. hlm. 351-360. Dalam B. Kartiwa, E. Runtunuwu, Subowo, M. Anda, A. Dariah, Mukhlis, A. Nugraha, dan P. Setyanto (Ed.). Proceeding of the National Seminar on Agricultural Land Resources. 1st Book. Center for Research and Development of Agricultural Land Resources.

[17] Rina, Y. 2011. Aspek sosial ekonomi komoditas jeruk siam di lahan rawa. hlm. 333-350. In B. Kartiwa, E. Runtunuwu, Subowo, M. Anda, A. Dariah, Mukhlis, A. Nugraha, dan P. Setyanto (Ed.). Proceeding of the National Seminar on Agricultural Land Resources. 2nd Book. Center for Research and Development of Agricultural Land Resources.

[18] Rohmah W., Suryantini A, and S. Hartono. 2014. Analisis Pendapatan Dan Tingkat
Kesejahteraan Rumah Tangga Petani Tebu Tanam Dan Keprasan Di Kabupaten Bantul. Agro Ekonomi Vol. 24 (1): 54-67

[19] Saragih, B. 2001. Agribisnis (Paradigma Baru Pembangunan Ekonomi Berbasis Pertanian). Yayasan Mulia Persada Indonesia. Bogor.

[20] Simatupang, P. 1988. Penentuan Ekonomi Skala Usaha dengan Fungsi Keuntungan: Landsasan Teoritis dengan Contoh Fungsi Cobb-Douglas dan Translog. Jurnal Agro Ekonomi Vol. 7: 1-16.

[21] Soekartawi. 2003. Teori Ekonomi Produksi dengan Pokok Bahasan Analisis CobbDouglas. PT RajaGrafindo Persada. Jakarta.

[22] Suriadikarta, D.A. 2011. Teknologi pengelolaan lahan gambut yang berkelanjutan. Pp:716-736. In I. Inounu, D.S. Damardjati, Supriadi, Bahagiawati, K. Diwyanto, Sumarno, I.W. Rusastra, dan Subandriyo (Ed.). Development of Science-Based Agriculture Based on Research Results. 2 nd Book. Agricultural Research and Development Agency Ministry of Agriculture. Jakarta.

[23] Surata, K. I. 2007. Pemanfaatan Irigasi Tetes Untuk Penanaman Cendana (Santalum album L.) di Lahan Kritis Banamblaat Pulau Timor Provinsi Nusa Tenggara Timur. Kupang Forestry Research Center. Kupang.

[24] Yotopoulos. 1972. Profit, Supply and Factor Demand Functions. American Journal of Agricultural Economics vol. 54 (1): 11-18. 